\title{
Application for 3D Interface using Augmented Reality
}

\author{
Shwetambari Kharabe, C. Nalini , R. Velvizhi
}

\begin{abstract}
Augmented reality (AR) has been used in the last years as a weapon for enhancing co-operation between the real world and virtual environments. The goal of this work is to develop an android application which will raise the value of tourist on-site experience in an innovative way via $A R$ technology. This survey will especially focuses on museum tourism. Museum consisting of distinct sections faces difficulties of tourist management. If guides are not accessible this application can take place of human guide. In historical section of museum, one can scan the $2 D$ image of object and can gain its $3 D$ view along with its information. In music section, tourist can scan the image of singer and application will play famous melodies related to that singer. This data will be stored on the Cloud. This application is done by using well known technologies such as Unity $3 D$ and Vuforia. Usage of such tools and technologies gives great opportunity to convert imagination into reality.
\end{abstract}

Keywords: Augmented Reality, Augmented Reality based 3D display, Augmented Reality based Music Player, Cloud Computing.

\section{INTRODUCTION}

Extended reality (AR) is a live quick or roaming point of view on a physical, authentic condition whose reasonable depiction are developed (or upgraded) by PC created material data, for instance, sound, video, PC structures workmanship or GPS data. [1],[3],[5]

Expanded reality applications are written in indisputable 3D programs that help the originator to join movement or significant automated information in the PC structure to an extended world "marker" as a general rule. Exactly when a figuring contraption's AR application or program module gets mechanized information from a known marker, it begins to execute the marker's code and layer the correct picture or pictures.

\section{PROPOSED SYSTEM}

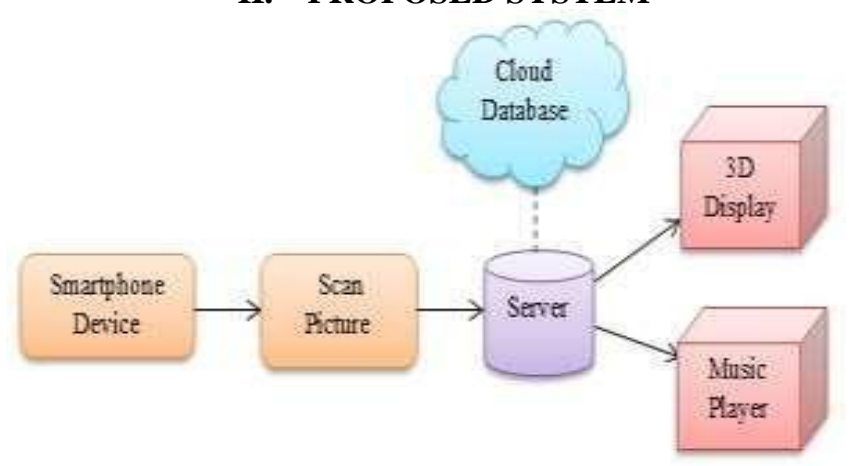

Revised Manuscript Received on August 22, 2019.

Shwetambari Kharabe Department of CSE,Bharath Institute of Higher Education \& Research,TamilNAdu Email: shweta.chiwhane@gmail.com

C. Nalini, Department of CSE,Bharath Institute of Higher Education \& Research,TamilNAdu Email:nalinicha2002@gmail.com

R. Velvizhi, Department of CSE,Bharath Institute of Higher Education \& Research,TamilNAdu Email: velvizhisp@gmail.com
In proposed system, we have used predefined markers for recognition. As shown in above Fig.1. User scans marker image through his/her Smartphone device. System will scan the marker and process to system server. All data is stored in cloud database. System server checks cloud data for corresponding visuals and displays the $3 \mathrm{D}$ view of available information. If user scans the marker and if its related music is available then system will start music player and play the music. If no information is available in database then system will generate error "No information is available".

\section{RESULTS}

In proposed system, we have used predefined markers for recognition. As shown in above Fig.1. User scans marker image through his/her Smartphone device. System will scan the marker and process to system server. All data is stored in cloud database. System server checks cloud data for corresponding visuals and displays the 3D view of available information [6]. If user scans the marker and if its related music is available then system will start music player and play the music. If no information is available in database then system will generate error "No information is available".

We proposed a novel framework for museum tourism which makes use of Smartphone to recognize image markers. System consist of local cloud instead of global cloud database. Because it is cost efficient and convenient for small scale user. [2 ],[4],[6]

Through the login page user will connect to local cloud server by providing appropriate username and password. Before this user have to register. User information will be stored on local cloud database. [8],[10], [12]

System provides multiple languages, which includes English as well as regional language i.e., Marathi. User can select language as per their convenience. [19],[21], [20],

After selecting the language AR camera will start. User have to scan the image markers then four toggle buttons will appear on screen which provides different choices such as information, audio, 3D model, video

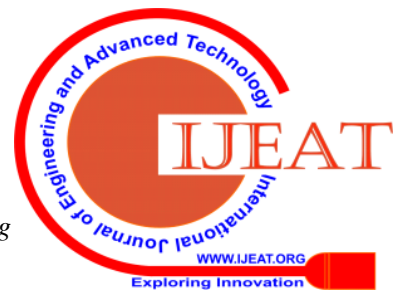




\section{Application for 3D Interface using Augmented Reality}

\section{FUTURE WORK}

This framework gives an easy to understand interface which would intuitively get data. As future work, expanding the picture acknowledgment precision rate and lift the all out speed of procedure is the primary activity, with the goal that the preparing time required will be less. Adding highlight to output pictures other than predefined pictures will ease client to recover data. We will give progressively intuitive offices of data recovery and let clients feel advantageous. [13], [15] ,[17]

\section{CONCLUSION}

In this paper we have clarified a framework for the client will most likely view articles present in gallery in 3D see and can listen music of prevalent vocalists. Enlarged Reality (AR), a developing Human-Computer Interaction innovation, which plans to blend or cover PC created 2D or 3D virtual articles and other input with true scenes. This new methodology offers client to learn things by envisioning in genuine world. This framework gives easy to understand interface which is based on cloud engineering. [14],[16], [18]

\section{REFERENCES}

1. Sharma, R.K., Irusapparajan, G. \& Periyaazhagar, D. 2019, "Three-phase symmetric cascading Z-source seven levels multilevel inverter excited by multi carrier sinusoidal pulse width modulation scheme", International Journal of Innovative Technology and Exploring Engineering, vol. 8, no. 10 , pp. 4269-4274.

2. Velavan, R., Bharanidharan, S. \& Sheeba, B. 2019, "EMF pollution Causes, effects and protection", International Journal of Innovative Technology and Exploring Engineering, vol. 8, no. 9 Special Issue 3, pp. 1166-1168.

3. Saravana, S., Balaji, S., Arulselvi, S. \& John Paul Praveen, A. 2019, "Reliable power quality monitoring and protection system", International Journal of Innovative Technology and Exploring Engineering, vol. 8, no. 9 Special Issue 3, pp. 644-645.

4. Tamil Selvan, S. \& Sundararajan, M. 2019, "Performance Parameters of 3 Value 8t Cntfet Based Sram Cell Design Using H-Spice", International Journal of Recent Technology and Engineering, vol. 8, no. 2 Special issue 5, pp. 22-27.

5. Jac Fredo, A.R., Abilash, R.S., Femi, R., Mythili, A. \& Kumar, C.S. 2019, "Classification of damages in composite images using Zernike moments and support vector machines", Composites Part B: Engineering, vol. 168 , pp. $77-86$

6. Kathiravan, P. \& Govindaraju, C. 2019, "Design and evaluation of ultra gain isolated DC-DC converter for photovoltaic system", International Journal of Engineering and Advanced Technology, vol. 8, no. 5, pp. 2646-2651.

7. Kripa, N., Vasuki, R. \& Kishore Kanna, R. 2019, "Realtime neural interface controlled au-pair BIMA bot", International Journal of Recent Technology and Engineering, vol. 8, no. 1, pp. 992-994.

8. Mohanraj, Meenaa Kumari, M., Philomina, S. \& Jasmin, M. 2019, "In-situ humidity measurement of hydrogen fuel cell car using MEMS sensor", International Journal of Recent Technology and Engineering, vol. 8, no. 1, pp. 41-43.

9. Velmurugan, T. \& Prakash, S. 2019, "Artificial intelligent based distribution automation of swift fault detection isolation and power restoration for HT network", International Journal of Innovative Technology and Exploring Engineering, vol. 8, no. 6, pp. 1-6.

10. Dwarakesh, K. \& Prem Kumar, G. 2019, "Five-level inverter based sequential boost system using fuzzy logic controller", International Journal of Innovative Technology and Exploring Engineering, vol. 8, no. 6, pp. 12-19.

11. Anne Gifta, A. \& Hemavathi, G. 2019, "Analysis of grid tied solar PV system using ANFIS Algorithm", International Journal of Innovative Technology and Exploring Engineering, vol. 8, no. 6, pp. 312-316.

12. Jayavel, R., Rangaswamy, T.R. \& Prakash, S. 2019, "Efficient grid management system with renewable and conventional power sources", International Journal of Innovative Technology and Exploring Engineering, vol. 8, no. 6, pp. 287-289.
13. Hemavathi, G. \& Maheshwaran, S. 2019, "Proportional resonant controlled high gain step-up converter system with improved response", International Journal of Innovative Technology and Exploring Engineering, vol. 8, no. 6, pp. 317-323.

14. Periyaazhagar, D. \& Irusapparajan, G. 2019, "Design and completion of asymmetric single phase 27 level cascaded mli for various pwm scheme", International Journal of Innovative Technology and Exploring Engineering, vol. 8, no. 6, pp. 792-797.

15. Mahalakshmi, V. \& Vijayaragavan, S.P. 2019, "PV based power electronic converters for high voltage DC applications", International Journal of Recent Technology and Engineering, vol. 7, no. 6, pp. 670-674.

16. Irusapparajan, G., Periyaazhagar, D., Prabaharan, N. \& Rini Ann Jerin, A. 2019, "Experimental verification of trinary DC source cascaded h-bridge multilevel inverter using unipolar pulse width modulation", Automatika, vol. 60, no. 1, pp. 19-27.

17. Sangeetha, G., Sherine, S., Arputharaju, K. \& Prakash, S. 2019, "On Line Monitoring of Higher Rated Alternator using Automated Generator Capability Curve Administer", Proceedings of the IEEE International Conference on \&amp;quot;Recent Trends in Electrical, Control and Communication\&amp;quot; RTECC 2018, pp. 176.

18. Bycil, V.J. \& Wiselin, M.C.J. 2019, "Modeling and analysis of vibration energy harvesting system using piezo stack", International Journal of Mechanical and Production Engineering Research and Development, vol. 9, no. Special Issue 1, pp. 523-533.

19. Sripada, A., Warrier, A., Kapoor, A., Gaur, H. \& Hemalatha, B. 2018, "Dynamic lateral balance of humanoid robots on unstable surfaces", International Conference on Electrical, Electronics, Communication Computer Technologies and Optimization Techniques, ICEECCOT 2017, pp. 539.

20. Srinivasan, S., Thirumalaivasan, K. \& Sivakumaran, T.S. 2018, "Performance evaluation of double-output luo converters", Journal of Advanced Research in Dynamical and Control Systems, vol. 10, no. 10 Special Issue, pp. 870-878.

21. Karthikayen, A. \& Selvakumar Raja, S. 2018, "A skellam distribution inspired trust factor-based selfish node detection technique in MANETs", Journal of Advanced Research in Dynamical and Control Systems, vol. 10, no. 13, pp. 940-949.

\section{AUTHORS PROFILE}

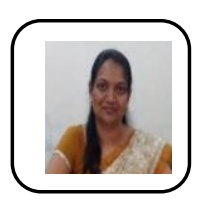

Shwetambari Kharabe, Research Scholar,Department of CSE,Bharath Institute of Higher Education \& Research,TamilNAdu

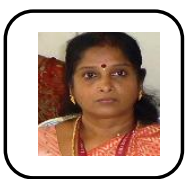

C. Nalini, Professor,Department of CSE,Bharath Institute of Higher Education \& Research,TamilNAdu

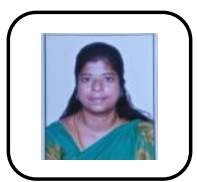

R. Velvizhi, Assistant Professor,Department of CSE,Bharath Institute of Higher Education \& Research,TamilNAdu 